\title{
Balloon-Assisted Endovascular Treatment of Intracranial Dural Arteriovenous Fistulas
}

\section{Intrakraniyal Dural Arteriyovenöz Fistüllerin Balon Yardımln Endovasküler Tedavisi}

\author{
Xiaochuan HUO, Youxiang LI, Chuhan JIANG, Zhongxue WU \\ Capital Medical University, Beijing Neurosurgical Institute and Beijing Tiantan Hospital, Beijing, China
}

Corresponding Author: Youxiang LI / E-mail: doctorliyouxiang@163.com

\begin{abstract}
AIM: Most dural arteriovenous fistulas (DAVFs) can be treated safely and effectively with endovascular Onyx embolization. Balloon-assisted endovascular Onyx embolization of intracranial DAVFs is especially suitable for arterial protection and arterial flow reduction in complicated DAVFs. We systemically report our experience in the use of arterial balloon for Onyx embolization of DAVF and evaluate the clinical outcomes.

MATERIAL and METHODS: Clinical records of 12 consecutive DAVFs patients (five women, seven men) treated with arterial balloon-assisted endovascular Onyx embolization were retrospectively collected to analysis their presenting symptoms, angiographic features, endovascular treatments, and clinical outcomes.

RESULTS: Six patients presented with cortical venous reflux (CVR). Nine patients underwent transarterial (TA) and 3 patients underwent transvenous (TV) embolization. The balloons were used in 3 types of approach: arterial protection in TA embolization, arterial flow reduction in TA embolization and arterial protection in TV approach. Angiograms demonstrated complete obliteration of the fistula in 11 patients and partial occlusion in one. One patient had Onyx embolization-related complication of transient hemi-facial hypoesthesia.

CONCLUSION: The Arterial balloon provides protection of intracranial artery and reduction of arterial flow in Onyx embolization of DAVF. This complementary method brought high cure rate.
\end{abstract}

KEYWORDS: Dural arteriovenous fistula, Embolization, Balloon, Onyx

Öz

AMAÇ: Çoğu dural arteriyovenöz fistül (DAVF) endovasküler Onyx embolizasyonuyla güvenli ve etkin bir şekilde tedavi edilebilir. İntrakraniyal DAVF'lerin balon yardımlı endovasküler Onyx embolizasyonu özellikle komplike DAVF'lerde arteriyel akışı azaltma ve arteri koruma için uygundur. DAVF için Onyx embolizasyonu amaçlı arteriyel balon kullanımı deneyimimizi bildiriyor ve klinik sonuçları değerlendiriyoruz.

YÖNTEM ve GEREÇLER: Arteriyel balon yardımlı endovasküler Onyx embolizasyonuyla tedavi edilen 12 DAVF hastasının (beş kadın, yedi erkek) klinik kayıtları, geliş belirtileri, anjiyografik özellikleri, endovasküler tedavileri ve klinik sonuçları analiz edilmek üzere retrospektif olarak toplandı.

BULGULAR: 6 hasta kortikal venöz reflü (KVR) ile geldi. Dokuz hastaya transarteriyel (TA) ve 3 hastaya transvenöz (TV) embolizasyon yapıldı. Balonlar 3 tür yaklaşımda kullanıldı:TA embolizasyonda arteriyel koruma, TA embolizasyonda arteriyel akış azaltma ve TV yaklaşımında arteriyel koruma. Anjiyogramlar 11 hastada fistülün tam obliterasyonu ve bir hastada kısmi oklüzyon gösterdi. Bir hastada Onyx embolizasyonuyla ilgili olarak geçici hemifasiyal hipoestezi komplikasyonu vardı.

SONUÇ: Arteriyel balon, DAVF'nin Onyx embolizasyonunda intrakraniyal arterin korunmasını ve arteriyel akışın azaltılmasını sağlamaktadr. Bu tamamlayıc yöntem düşük bir komplikasyon oranına sahiptir ve yüksek bir tam iyileşme oranıyla sonuçlanmıştır.

ANAHTAR SÖZCÜKLER: Dural arteriyovenöz fistül, Embolizasyon, Balon, Onyx

ABBREVIATIONS: MCA: middle cerebral artery, CCA: common carotid artery, ICA: internal carotid artery, SAH: subarachnoid hemorrhage, BAC: balloon-assisted coiling, CVR: cortical venous reflux, DAVF: dural arteriovenous fistula, ECA: external carotid artery, MMA: middle meningeal artery, OA: occipital artery, TDAVF: tentorial DAVF, CS: cavernous sinus, CV: cortical vein, IPS: inferior petrosal sinus, SPS: superior petrosal sinus, SSS: superior sagittal sinus, SOV: superior ophthalmic vein, PAA: posterior auricular artery, AMA: accessory meningeal artery, PMA: posterior meningeal artery, SR: sinus ractus, TS-SS: transverse sinus and sigmoid sinus. 


\section{INTRODUCTION}

The balloon-assisted technique was incipiently used in the embolization of wide-neck aneurysm with coils or Onyx. The balloon helped to shape the coil or control the migration of Onyx during embolization. Balloons were also used to block blood supply and detachable balloons were used in the treatment of carotid cavernous sinus fistula. The balloonassisted technique in DAVF embolization was reported in some cases to control Onyx migration. But the use of balloon aiming to protect intracranial arteries in DAVF was not reported so far. We systemically describe the use of arterial balloon in the embolization of 12 consecutive intracranial DAVFs patients and evaluate the benefits.

\section{MATERIAL and METHODS}

Patients with intracranial DAVFs treated with Onyx embolization between August 2007 and August 2012 were retrospectively reviewed. During this period, 12 patients were treated with Onyx embolization adjunct to arterial balloonassisted technique. There were 5 women and 7 men with ages ranging from 18 to 66 (mean age 43 years). One patient presented with the symptom of intracranial hemorrhage, 6 with progressive headaches, 3 with tinnitus, and 4 with chemosis. One patient in this series has been reported previously (7) (Table I).

\section{Angiographic Analysis}

Based on the presence of cortical or retrograde venous sinus drainage, 7 DAVFs were classified as Cognard lla, 1 lesions as III, 3 lesions as IV and 1 lesions as V. The arterial supplies were the middle meningeal artery (MMA), meningeal hypophyseal artery (MHA) and posterior meningeal artery (PMA). Of the 12 DAVFs, 1 DAVF located at the transverse and sigmoid sinus (TS-SS), 7 located at the cavernous sinus (CS) and 4 located at the tentorium.

\section{Endovascular Procedure}

Nine patients underwent transarterial onyx embolization and 3 patients underwent transvenous onyx embolization. All the patients were placed under general anesthesia and transfemoral arteriography was performed. Systemic heparinization was achieved during the procedures with heparin $5,000 \mathrm{U}$ bolus followed by $1,000 \mathrm{U}$ of heparin every hour.

\section{TECHNIQUE}

\section{Transarterial}

After a guiding catheter was placed into the feeding artery via a transfemoral approach, feeders of DAVF were selectively catheterized with a microcatheter (Marathon; MTI-EV3, Irvine, CA, USA) over microwire (Mirage, MTI-EV3, Irvine, CA, USA). For lesion cures, Onyx-18 was used as the embolic agent in attempt to "push" the Onyx across the arteriovenous shunts and into the proximal draining vein.

In 11 patients, the balloon was placed in the ICA or VA during the injection of Onyx-18. During injection of Onyx, the balloon was temporarily inflated to prevent migration of onyx into intracranial arteries. The balloon was deflated during the long interval of onyx injection and the one continuous balloon inflation was less than five minutes.

In 1 patient, the balloon catheter was positioned in the feeding artery proximal to the tip of microcatheter. During injection of Onyx, the balloon was temporarily inflated to increase proximal resistance, aid plug formation in fistulas and control distal Onyx migration, resulting in better control of reflux and enhanced distal penetration.

\section{Transvenous}

In three cases we used the transvenous embolization.

Table I: Clinical and Angiographic Characterization in 12 Patients with DAVFs

\begin{tabular}{|c|c|c|c|c|c|}
\hline Age/sex & Location & Presentation & Cognard type & Suppliers & Venous drainage \\
\hline $66 / M$ & Rt CS & Headache \& chemosis & Ila & Rt MHA, Rt MMA & IPS,SOV \\
\hline $18 / F$ & Lt Tentorium\& CS & Headache & IV & $\begin{array}{l}\text { Lt MHA, Lt MMA (petrosqua- } \\
\text { mosal branch)\&OA\&AMA, }\end{array}$ & $C V$, varix \\
\hline 29/M & Rt Tentorium & Headache & III & Rt MHA, MMA, AMA & $\mathrm{CV}$ \\
\hline $45 / F$ & Lt TS-SS & Tinnitus & Ila & $\begin{array}{l}\text { Rt MMA(posterial \& petrosqu- } \\
\text { amosal branch),OA,PAA }\end{array}$ & $\mathrm{TS}, \mathrm{SS}$ \\
\hline $50 / M$ & Lt CS, SPS & SAH & IV & Lt MHA, MMA & SPS, CV \\
\hline $44 / M$ & Lt Tentorium & $\mathrm{ICH}$, tinnitus & II & Lt OA,PMA & $C V$, varix \\
\hline $38 / F$ & Rt CS & Chemosis & Ila & Rt MHA,MMA & IPS,SOV \\
\hline $43 / M$ & Rt Tentorium \& CS & Headache & Ila & Rt MHA,MMA & Tentorium \\
\hline $41 / M$ & Lt CS & Chemosis & IVa & Rt MHA, Lt MMA & IPS,SOV \\
\hline $52 / M$ & Rt CS, SPS & Chemosis & II & Rt MHA, MMA & $C V$, varix \\
\hline $55 / F$ & Rt CS & Headache \& tinnitus & Ila & Rt MHA, MMA & TS,SS \\
\hline $39 / F$ & Lt CS & Headache & II & Lt MHA, MMA & TS,SS,CV \\
\hline
\end{tabular}

CS: Cavernous sinus, F: Female, Lt: Left, M: Male, Rt: Right, SPS: Superior petrosal sinus, TS-SS: Transverse sinus and sigmoid sinus. 
6-Fr sheath was placed in the femoral artery and vein. 5-Fr catheter was placed in the carotid artery to allow observation of the shunt, acquisition of roadmaps, angiographic monitoring of the procedure and position the balloon catheter to the feeding artery of MHA. The balloon was inflated in MHA segment of ICA when performing the Onyx embolization. A second 5-Fr catheter was positioned in the internal jugular vein. A microcatheter (Echelon10; MTI-EV3, Irvine, CA, USA) was navigated via internal jugular vein. The microcatheter was the carefully introduced and advanced to the CS via inferior petrosal sinus followed by the microwire. Embolization was performed with soft electrically detachable coils and combination with Onyx-18 or Onyx-34 under realtime digital subtraction fluoroscopic mapping.

Patient outcomes were clinically graded at follow-up evaluation after discharge from the hospital. Clinical outcome was graded according to the modified Rankin score (mRS) (4).

\section{RESULTS}

A total of 9 transarterial and 3 transvenous Onyx injection were performed adjunct to arterial balloon-assisted technique. Five transarterial Onyx embolizations were performed via MMA, 2 via MHA, 1 via MHA \&MMA and 1 via PMA. Three transvenous embolizations were performed via IPS to CS (Table I).

There were 10 sessions of balloon inflation in the ICA and 1 in the vertebral artery to provide protection. Another 1 session of balloon inflation was in the MMA to decrease the blood flow. Immediately following embolization, there was complete occlusion in 11 patients and partial occlusion in 1. The fistula was incompletely occluded because of early termination due to distal Onyx migration. This patient had a complex arterial supply and further treatment (endovascular or surgical) would be according to following angiography and clinical symptom.

Table II: Summary of Endovascular Treatment, Angiographic Results, and Clinical Outcomes

\begin{tabular}{|c|c|c|c|c|c|c|c|c|c|}
\hline Patient & $\begin{array}{c}\text { Treat- } \\
\text { ment } \\
\text { strategy }\end{array}$ & $\begin{array}{l}\text { Emboliza- } \\
\text { tion route }\end{array}$ & $\begin{array}{l}\text { Balloon } \\
\text { route }\end{array}$ & $\begin{array}{l}\text { Balloon } \\
\text { type }\end{array}$ & Onyx & $\begin{array}{l}\text { Angiog- } \\
\text { raphic } \\
\text { results }\end{array}$ & $\begin{array}{c}\text { Complicati- } \\
\text { ons }\end{array}$ & $\begin{array}{c}\text { Follow- } \\
\text { up } \\
\text { (months) }\end{array}$ & $\begin{array}{l}\text { Clinical } \\
\text { outcome } \\
\text { (mRS) }\end{array}$ \\
\hline 1 & $\begin{array}{l}\text { TVE \& } \\
\text { coiling }\end{array}$ & Rt IPS,CS & Rt ICA & $\begin{array}{c}\text { HyperGlide } \\
4^{*} 20 \mathrm{~mm}\end{array}$ & Onyx-34 & Complete & None & 29 & 0 \\
\hline 2 & TAE & Lt MMA & Lt ICA & $\begin{array}{c}\text { HyperGlide } \\
4^{*} 20 \mathrm{~mm}\end{array}$ & Onyx-18 & Complete & None & 27 & 0 \\
\hline 3 & TAE & $\begin{array}{l}\text { Rt MHA, } \\
\text { MMA }\end{array}$ & Rt ICA & $\begin{array}{c}\text { HyperGlide } \\
4^{*} 20 \mathrm{~mm}\end{array}$ & Onyx-18 & Complete & $\begin{array}{c}\text { Hemifacial } \\
\text { hypoesthesia }\end{array}$ & 12 & 0 \\
\hline 4 & TAE & Rt MMA & Rt MMA & $\begin{array}{c}\text { Hyperform } \\
4^{*} 7 \mathrm{~mm}\end{array}$ & Onyx-18 & partial & None & 16 & 0 \\
\hline 5 & TAE & Lt MMA & Lt ICA & $\begin{array}{c}\text { Hyperform } \\
4^{*} 7 \mathrm{~mm}\end{array}$ & Onyx-18 & Complete & None & 21 & 0 \\
\hline 6 & TAE & Lt PMA & Lt VA & $\begin{array}{l}\text { HyperGlide } \\
4^{*} 20 \mathrm{~mm}\end{array}$ & Onyx-18 & Complete & None & 66 & 0 \\
\hline 7 & $\begin{array}{c}\text { TVE \& } \\
\text { coiling }\end{array}$ & Rt IPS,CS & Rt ICA & $\begin{array}{l}\text { HyperGlide } \\
4^{*} 20 \mathrm{~mm}\end{array}$ & Onyx-34 & Complete & None & 17 & 0 \\
\hline 8 & TAE & Rt MHA & Rt ICA & $\begin{array}{l}\text { HyperGlide } \\
4^{*} 20 \mathrm{~mm}\end{array}$ & Onyx-18 & Complete & None & 32 & 0 \\
\hline 9 & $\begin{array}{l}\text { TVE \& } \\
\text { coiling }\end{array}$ & Rt IPS,CS & Rt ICA & $\begin{array}{l}\text { HyperGlide } \\
4^{*} 20 \mathrm{~mm}\end{array}$ & Onyx-18 & Complete & None & 16 & 0 \\
\hline 10 & TAE & Rt MMA & Rt ICA & $\begin{array}{c}\text { HyperGlide } \\
4^{*} 20 \mathrm{~mm}\end{array}$ & Onyx-18 & Complete & None & 22 & 0 \\
\hline 11 & TAE & Rt MMA & Lt ICA & $\begin{array}{c}\text { Hyperform } \\
4^{*} 7 \mathrm{~mm}\end{array}$ & Onyx-18 & Complete & None & 28 & 0 \\
\hline 12 & TAE & Lt MHA & Lt ICA & $\begin{array}{c}\text { HyperGlide } \\
4^{*} 20 \mathrm{~mm}\end{array}$ & Onyx-18 & Complete & None & 13 & 0 \\
\hline
\end{tabular}

CS: Cavernous sinus, ICA: Internal carotid artery, IPS: Inferior petrosal sinus, Lt: Left, MHA: Meningeal hypophyseal artery, MMA: Middle meningeal artery, mRS: Modified Rankin score, PMA: Posterior meningeal artery, Rt: Right, TAE: Transarterial embolization, TS-SS: Transverse and sigmoid sinus, TVE: Transvenous embolization. 
There were no difficulties or complications involving balloon inflation, deflation, or retrieval. No untoward embolization into the cerebral circulation occurred. One patient had the complications of transient right facial hemihypoesthesia. All other patients experienced complete resolution of their clinical symptoms. At the time of discharge, all the patients had a mRS of 0 (Table II).

\section{ILLUSTRATIVE CASES}

\section{Patient 1 (arterial protection in TA embolization)}

This 29-year-old man developed a headache and dizzy for about 10 years. Cerebral angiography revealed a DAVF involving the right tentorium (Figure 1A). The artery supply was from the MHA. We navigated a microcatheter into MHA of right ICA to get a position optimal for Onyx injection. A HyperGlide balloon $(4 * 20$, MTI-EV3, Irvine, CA, USA) was advanced into the MHA segment of ICA for protection (Figure $1 \mathrm{~B})$. Transarterial balloon occlusion produced good protection of intracranial feeding artery. Angiography after transarterial Onyx-18 embolization showed complete obliteration of the lesion (Figure 1C). The patient's symptoms were completely resolved after the procedure.

\section{Patient 2 (arterial flow reduction in TA embolization)}

This 45-year-old woman presented with tinnitus for 3 months. Cerebral angiography revealed a DAVF involving the right TSSS (Figure 2A). The artery supply was from the posterior branch and petrosquamosal branch of right $M M A$, right occipital artery (OA) and right posterior auricular artery (PAA). We navigated a microcatheter into posterior branch of right MMA to get a position optimal for Onyx injection. A HyperGlide balloon (4*20, MTI-EV3, Irvine, CA, USA) was advanced into the MMA to control the migration of onyx (Figure 2B). Transarterial balloon occlusion produced good control of blood supply from MMA and provided a more effective penetration. Angiography after transvenous embolization Onyx-18 showed partial obliteration of the lesion. The residual lesion was supplied by the petrosquamosal branch of right MMA, right $\mathrm{OA}$ and right PAA (Figure $2 \mathrm{C}$ ). The tinnitus symptoms were completely resolved after the procedure.

\section{Patient 3 (arterial protection in TV approach)}

This 38-year-old woman presented with right eye chemosis. Cerebral angiography revealed a DAVF involving the right CS (Figure 3A). Transvenous approach was used through IPS to

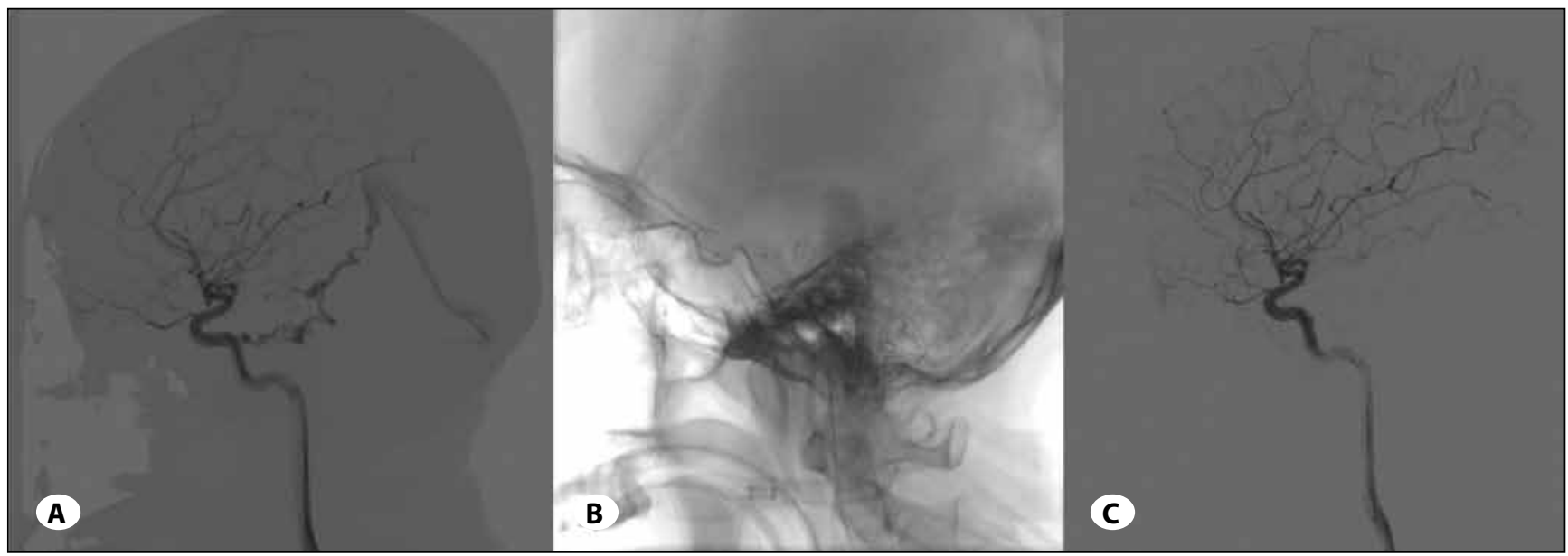

Figure 1: A) Cerebral angiography revealed a DAVF involving the right tentorium. B) A Hyperglide balloon was advanced into the MHA segment of ICA for protection. C) Angiography after transvenous embolization Onyx-18 showed completely obliteration of the lesion.

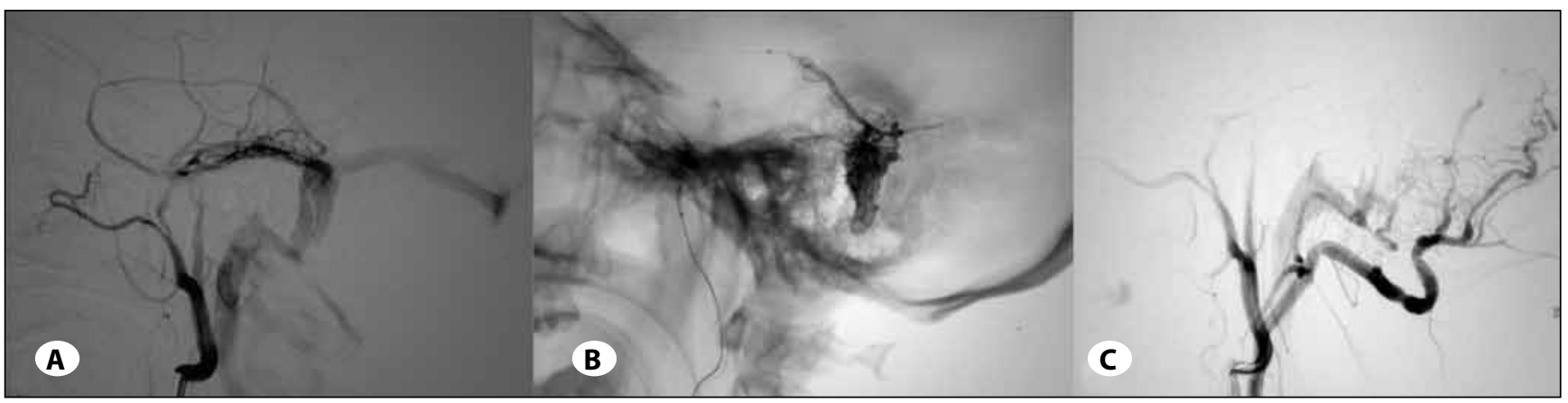

Figure 2: A) Cerebral angiography revealed a DAVF involving the right TS-SS. The artery supply was from the posterior branch and petrosquamosal branch of right MMA, right OA and right PAA. B) A Hyperglide balloon was inflated the MMA to control the migration of onyx. C) Angiography after transvenous embolization Onyx-18 showed partial obliteration of the lesion. The residual lesion was supplied by the petrosquamosal branch of right MMA, right OA and right PAA. 


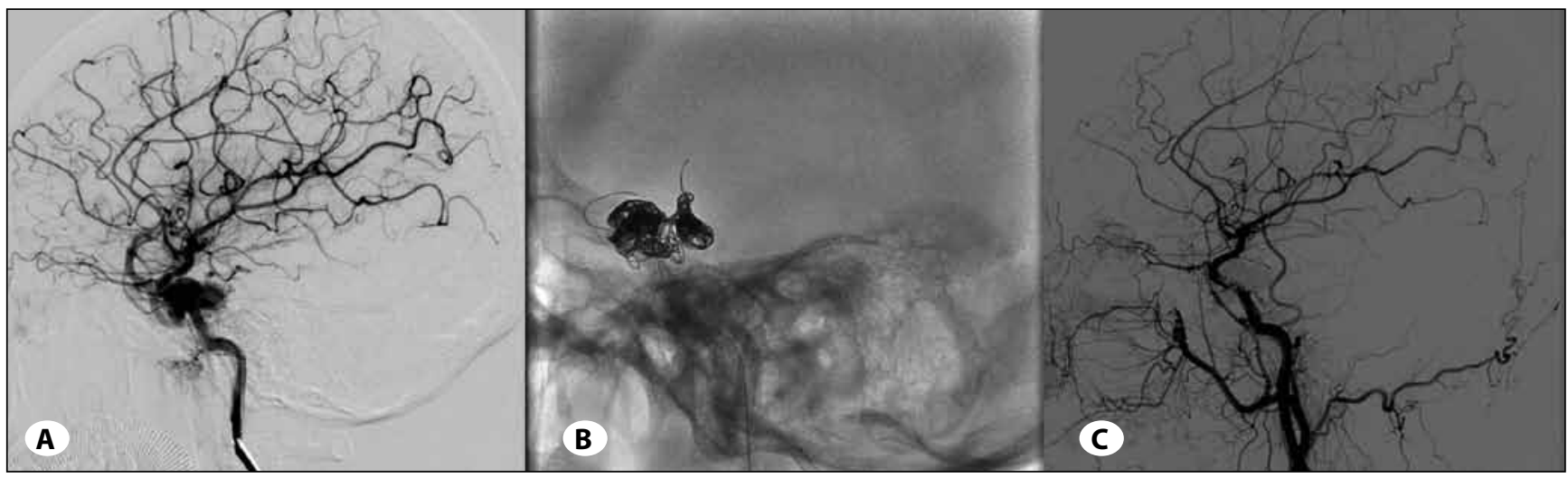

Figure 3: A) Cerebral angiography revealed a DAVF involving the right CS. The artery supply was from the MHA. B) A Hyperglide balloon was advanced into the MHA segment of ICA for protection. C) Follow up angiography after transvenous embolization Onyx-34 showed completely obliteration of the lesion.

right CS and coils were detached before Onyx embolization. Right CS was transvenously catheterized and the right MHA segment of ICA was protected with a HyperGlide balloon (4*20, MTI-EV3, Irvine, CA, USA) (Figure 3B). Embolization was performed by repeating transvenous injection of Onyx 34 through right CS in combination with the arterial BAT in the ICA, and followed by injection of Onyx 18 into CS. Transarterial balloon occlusion produced good protection of ICA. Angiography showed complete occlusion of the DAVF (Figure 3C). The patient's symptoms improved after the procedure and were completely resolved at follow-up.

\section{DISCUSSION}

The aggressive type of intracranial DAVF with either direct or indirect retrograde filling of a leptomeningeal vein has a high propensity of ischemia, intracranial hypertension, and cerebral bleeding (17). If left untreated, the mortality rate is $10.4 \%$, the annual bleeding and the non-hemorrhagic neurological deficit risks are $8.1 \%$ and $6.9 \%$, respectively. Therefore, consensus exists, that aggressive-type DAVFs should be treated $(2,5,9,18)$.

Onyx-based embolization is a promising technique option as a definitive treatment for DAVFs(3, 10-12). For DAVFs with high flow, easy reflux or anastomosis with intracranial vessels, it would not be an easy deal to make a better control of Onyx penetration into the fistula. Improper flow or reflux of Onyx may cause unfavorable embolization or even serious complications leaving unexpected prognosis (14).

Balloon-assisted technique was proposed for the endovascular treatment of broad-based aneurysms since the late 1990s. Balloon-assisted transarterial Onyx embolization of craniofacial vascular malformations or DAVFs has been described in other small series $(1,13)$. Rezende et al. (13) reported the usage of a temporary balloon in the ophthalmic segment of the ICA during transarterial Onyx embolization via the MMA to treat a sphenoparietal DAVF. This technique prevented the untoward passage of Onyx into the ICA via the recurrent meningeal branch of the $\mathrm{OA}$, and complete occlusion of the fistula was achieved with a single injection. Arat et al. (1) used the arterial Balloon-assisted technique through the external carotid artery (ECA) approach in 4 patients with highflow craniofacial vascular malformations during transarterial Onyx embolization. They reported difficulty with balloon deflation and retrieval in 1 patient due to extensive Onyx reflux. Zhong-Song Shi et al. (14) reported arterial BAT with Onyx not only perform flow control but also allow creation of a plug without the concomitant risk of catheter retention. All those cases reported were DAVFs related to SSS, TS or SS. However, treatment strategies of tentorial dural arteriovenous fistulas (TDAVFs) and CS are still debated for the difficulty in endovascular and surgical treatments because of multiple suppliers and deep location(16). Michael C. (6) reported a case of High-grade CS DAVF with balloon-assisted technique to protect CS, but embolization was aborted when the Onyx migrated into the intraorbital left lacrimal artery, given the risk of penetrating the ophthalmic artery. Finally, open surgical approach was combined in obliteration of this CS DAVF. However, our clinical experiences in the use of balloonassisted technique mainly facing the complex cases located in the tentorium or CS and the results are encouraging.

Some case reports first point out the balloon-assisted technique in embolization of DAVF can promote distal onyx migration. We use the balloon-assisted embolization in the feeding trunk of MMA to decrease the blood flow within the feeding artery in one DAVF patient. The balloon produced better control of the material's reflux and more distal penetration into the fistula by simulating a "wedged" effect. Decreasing the rapid flow of feeding artery could minimize the risk of distal migration of the embolic material into the systemic venous or pulmonary circulation caused by highflow shunting. Some rare complications were reported of Onyx migration causing symptomatic pulmonary complications of transarterial acrylic embolization of brain arteriovenous malformations (8).

The use of balloon may increase the incidence of ischemic affairs (15). But in our group, no balloon related complication 
occurred. The inflation duration of balloon should not exceed five minutes and intermittent deflation is recommended if the onyx injection duration lasts long.

In nine DAVFs cases related to CS, the feeding arteries were from both ECA and ICA. During transarterial Onyx injection through MMA or MHA, balloon was inflated in the feeding MHA opening to protect ICA. During Onyx injection transvenous through IPS, balloon was inflated in the feeding MHA opening not only to protect ICA but also decrease the flow rate in the CS. We inflated the balloon in the ICA at the site of the meningeal feeding arteries, which have anastomotic connections with the target vessel being embolized. The balloon could prevent Onyx from occluding the intracranial artery and/or causing distal embolism via those anastomotic channels. One tentorium DAVF patient with feeding artery of OA and PMA was embolized by inflated balloon in vertebral artery to provide protection of intracranial artery.

Complications occurred in the previously treated patients where a balloon was not used to protect intracranial feeding arteries or anastomotic arteries. In some previous patients, the MHA was blocked during onyx injection because of reflux or embolized through anastomotic connections. The balloon assisted embolization also presented a better total embolization rate. That might because of less reflux into feeding artery or influx into anastomotic arteries which provided a better control of onyx and a longer injection time for the elimination of the fistula.

It should be noted, however, no clear consensus exists on the best embolization strategy in complicated cases. We used the balloon-assisted embolization in one case to produced better control of the Onyx reflux and made more distal penetration into the fistula. For another 11 cases, our clinical experience hold the idea that when the DAVFs located in the tentorium or CS and supplied by both ECA and ICA, balloon is better used to protect the intracranial anastomosis artery. But some cases with no feeding MHA showed recurrent of Onyx into MHA and lead to clinical symptoms. This novel technique cannot substitute for proper use of the reflux-hold-reinjection technique.

\section{CONCLUSIONS}

Balloon adjunct to Onyx embolization can provide protection of intracranial artery in the treatment of intracranial DAVFs as a complementary method.

\section{REFERENCES}

1. Arat A, Cil BE, Vargel I, Turkbey B, Canyigit M, Peynircioglu $B$, Arat YO: Embolization of high-flow craniofacial vascular malformations with onyx. AJNR American Journal of Neuroradiology 28:1409-1414, 2007

2. Cheng KM, Chan CM, Cheung YL: Transvenous embolisation of dural carotid-cavernous fistulas by multiple venous routes: A series of 27 cases. Acta Neurochirurgica 145:17-29, 2003

3. Cognard C, Januel AC, Silva NA Jr, Tall P: Endovascular treatment of intracranial dural arteriovenous fistulas with cortical venous drainage: New management using Onyx. AJNR American Journal of Neuroradiology 29:235-241, 2008
4. de Haan R, Limburg M, Bossuyt P, van der Meulen J, Aaronson $\mathrm{N}$ : The clinical meaning of Rankin 'handicap' grades after stroke. Stroke 26:2027-2030, 1995

5. Houdart E, Saint-Maurice JP, Chapot R, Ditchfield A, Blanquet A, Lot G, Merland JJ: Transcranial approach for venous embolization of dural arteriovenous fistulas. Journal of Neurosurgery 97:280-286, 2002

6. Hurley MC, Rahme RJ, Fishman AJ, Batjer $\mathrm{HH}$, Bendok BR: Combined surgical and endovascular access of the superficial middle cerebral vein to occlude a high-grade cavernous dural arteriovenous fistula: Case report. Neurosurgery 69:E475-481; discussion E481-472, 2011

7. Jiang C, Lv X, Li Y, Zhang J, Wu Z: Endovascular treatment of high-risk tentorial dural arteriovenous fistulas: Clinical outcomes. Neuroradiology 51:103-111, 2009

8. Kjellin IB, Boechat MI, Vinuela F, Westra SJ, Duckwiler GR Pulmonary emboli following therapeutic embolization of cerebral arteriovenous malformations in children. Pediatric radiology 30:279-283, 2000

9. Lawton MT, Sanchez-Mejia RO, Pham D, Tan J, Halbach VV: Tentorial dural arteriovenous fistulae: Operative strategies and microsurgical results for six types. Neurosurgery 62:110124; discussion 124-115, 2008

10. Lucas Cde P, Mounayer C, Spelle L, Piotin M, Rezende MT, Moret J: Endoarterial management of dural arteriovenous malformations with isolated sinus using Onyx-18: Technical case report. Neurosurgery 61:E293-294; discussion E294, 2007

11. Lv X, Jiang C, Li Y, Wu Z: Embolization of intracranial dural arteriovenous fistulas with Onyx-18. European Journal of Radiology 73:664-671, 2010

12. Nogueira RG, Dabus G, Rabinov JD, Eskey CJ, Ogilvy CS, Hirsch JA, Pryor JC: Preliminary experience with onyx embolization for the treatment of intracranial dural arteriovenous fistulas. AJNR American Journal of Neuroradiology 29:91-97, 2008

13. Rezende MT, Piotin M, Mounayer C, Spelle L, Abud DG, Moret $\mathrm{J}$ : Dural arteriovenous fistula of the lesser sphenoid wing region treated with Onyx: Technical note. Neuroradiology 48:130-134, 2006

14. Shi ZS, Loh Y, Duckwiler GR, Jahan R, Vinuela F: Balloon-assisted transarterial embolization of intracranial dural arteriovenous fistulas. Journal of Neurosurgery 110:921-928, 2009

15. Spiotta AM, Bhalla T, Hussain MS, Sivapatham T, Batra A, Hui F, Rasmussen PA, Moskowitz SI: An analysis of inflation times during balloon-assisted aneurysm coil embolization and ischemic complications. Stroke 42:1051-1055, 2011

16. Tomak PR, Cloft HJ, Kaga A, Cawley CM, Dion J, Barrow DL: Evolution of the management of tentorial dural arteriovenous malformations. Neurosurgery 52:750-760; discussion 760752,2003

17. van Dijk JM, terBrugge KG, Willinsky RA, Wallace MC: Clinical course of cranial dural arteriovenous fistulas with long-term persistent cortical venous reflux. Stroke 33:1233-1236, 2002

18. van Rooij WJ, Sluzewski M, Beute GN: Dural arteriovenous fistulas with cortical venous drainage: Incidence, clinical presentation, and treatment. AJNR American Journal of Neuroradiology 28:651-655, 2007 